\title{
UTILIZATION OF THE GLUTARALDEHYDE COAGULATION TEST IN CATTLE
}

\author{
G. KOVAČ, P. MUDROŇ and M. MARTINČEK
}

Department of the Internal Diseases of Ruminants and Swine, University of Veterinary Science, 04181 Košice

This Daper is dedicated to the 60th birthday of Prof. MVDr. . Leopold Vrzgula, CSc.

Received December 22, 1986.

\section{A b s tract}

Kováč G., P. Mudroñ, M. Martinč ek: Utilization of the Glutaraldehyde Coagulation Test in Cattle. Acta vet. Brno, 56, 1987: 275-280.

Detection of inflammatory processes in adult cattle and detection of early and sufficient colostrum intake in newborn calves was carried out by means of the glutaraldehyde coagulation test. From a total of 368 blood-sampled dairy cows 108 showed a positive reaction within 6 minutes. Subsequent physical examination of these animals revealed actinomycosis, arthritis, bronchopneumonia, endometritis, urethritis, hepatitis, mastitis, pododermatitis, subcutaneous abscess, pericarditis, reticuloperitonitis and vaginitis. Among a total of 67 calves, 22 showed no blood serum coagulation, and their further examination revealed hypogammaglobulinemia caused in majority of animals by late colostrum intake. The simple principle of the glutaraldehyde test and rapidly achieved results make it a suitable tool for diagnostic and preventive measures of the veterinary practitioner.

Adult cattle, calves, $1.25 \%$ and $10 \%$ glutaraldehyde, inflammatory processes, hypogammaglobulinemia.

The development and maintenance of good herd health constitute the basic goal in enhancing production and reproduction of highly producing animals ( $\mathrm{YZzgula}$ et al. 1980). Although health of animals may be genetically related it may be greatly influenced by environmental factors such as nutrition, husbandry and management practices. A disruption of the balance between the organism and its environment makes itself felt to various degrees by disturbances in physiological functions. This results in generally poor condition and may produce clinical manifestations of disease. Moreover, it may predipose the animals, in particular 
the young; to parasitisms and infectious diseases ( $\mathrm{J}$ a go s et al. 1985). The present, large-scale units of animal production require efficient and effective diagnostic, therapeutic, and preventive health care measures.

One simple examination suitable for revealing inflammatory processes and for assessment of gammaglobulinemia is the glutaraldehyde coagulation test ( 5 a ndholm 1974b; Tennant et al. 1979).

In the diagnosis of infectious inflammatory processes the serum gammaglobulin fraction is of importance in addition to total protein concentration; their enhanced synthesis is indicative of the body's positive response to antigen stimulation. Chronic infections, especially purulent processes, result in sharp increase of the gammaglobulins. Data from the literature indicate the usefulness of the glutaraldehyde test coupled with the physical examination of test-positive animals (Schillinger 1982).

Materials and Methods

In this study, the glutaraldehyde coagulation test was employed. Its principle is the bonding of free amino groups by aldehydes. As glutaraldehyde contains 2 aldehyde groups per molecule, it is especially suitable for cross-linking with proteins. Among the blood proteins, gammaglobulins and fibrinogen contain reactive amino groups. When their blood concentration is elevated they polymerize after addition of glutaraldehyde (H O p W O O d 1969).

The test procedure for adult cattle was as follows: The testing reagent, a $1.25 \times$ solution of glutaraldehyde was prepared from its $25 \%$ aqueous solution diluted with saline and supplemented with $1 \mathrm{mg} / \mathrm{l} \mathrm{ml}$ EDTA. To this test reagent in a test tube equal amount of venous blood was added. The contents were mixed by inverting the tube $2-3$ times and the coagulation time in minutes. was determined.

Evaluation of test results:

Coegulation time in inutes

within 3

$3-6$

$7-15$

15
Gamaglobulin concentration

highly elevated moderetely elevated slightly elevated not elevated

In this study, 368 female cattle, 18 months of age or older, were employed. The enimals were examined at the Department of Internal Diseases, Diagnosis and Prevention, University of Veterinary Science, Kosice (clinical patients) and in the agricultur- 1 enterprise Zemplínske Teplice (production dairy cows). Animals with a coagulation time of more than 6 minutes were physically examined and routine screening examinations were performed of their ruminal contents, milk and urine.

The following test procedure was employed for detection of hypoand hypergammaglobulinemis in celves:

Fifty ul of $10 \times$ glutaraldehyde solution were added to $0.5 \mathrm{ml}$ blood serum.

Evaluation of the results:

Coagulation time was judged by holding the test tubes at an 
angle approaching horizontal a few times during 1 hour. With the satisfactory uptake of gammaglobulin by the calf from the first ingested colostrum, a conspicuous serum clot is formed by this procedure. With hypogammaglobulinemia, no clotting or only slight coagulation occurs (Tennant et al. 1979).

The glutaraldehyde test was used in $67 \mathrm{calves}$ (aged up to 1 month) born to or accompanying dams who were patients at.the University of Veterinary Science in Kosice, and from the agricultural enterprise in Zemplínske Teplice.

Results

Adult Cattle

Among 368 cows, 108 had a coagulation time of up to 6 minutes, 40 ranged from from 6 to 15 minutes:

Clinical examination was carried out in all animals that were within the 6 minute interval with following results:

\begin{tabular}{lc} 
Clinical findings & No. of cows \\
\hline Actinomycosis & 3 \\
Arthritis & 3 \\
Bronchopneumonia & 11 \\
Endometritis and urethritis & 12 \\
Hepatitis & 16 \\
Mastitis & 25 \\
Pericarditis & 2 \\
Pododermatitis, Rustelholtz ulcus & 21 \\
Subcutaneousabscesses & 5 \\
Reticuloperitonitis & 8 \\
Vaginitis & 2 \\
Ca ve s & \\
Of 67 calves 24 manifested no coagulation of blood sera at \\
60 minutes. This finding was indicative of hypogammaglobulinemia, \\
related principally to the late ingestion of colostrum. Further \\
serum analysis for gammaglpbulin concentration showed a borderline \\
concentration of 0.6 g.dl-1. Below this concentration only geli- \\
fication of the serum occurred.
\end{tabular}

Discussion

Contemporary veterinary practice requires rapid, simple, and reliable diagnostic methods enabling detection of subclinical disease and the predisposition to a variety of diseases.

As reported by several investigators ( $S$ a ndho $1 \mathrm{~m} \mathrm{1974ab;}$ Liberg 1981; Schilitinger 1982; Dollet al. 1985) and confirmed by our own data inflammatory processes in cattle can be detected by means of this test. During the initial inflammatory response, fibrinogen is the prevalent protein; with the advanced stage of the disease gammaglobulin predominated as a result of immune response. 
The possibility to employ this test was first described by S a n d hol $1 \mathrm{~m}$ (1974ab) who found that an increased gammaglobulin concentration in cattle can also be detected by means of a protein lability test; this is the principle of the glutaraldehyde coagulation test.

Schil 1 i nge r (1982) found that effectiveness of this test is dependent upon 1 ) the duration of the disease (with the initial immune response to antigen exposure, a sufficient increase in concentration of the serum globulin fraction occurs only at day 10$), 2$ ) by age of the animal (the immune system is developing throughout life and this test works best in animals older than 1 year), and by organ, or disease specifity (hypergammaglobulinemia is in any case organ-specific or disease-specific; i.e. its correct interpretation must be supported by information derived from the physical examination).

Dol 1 et al. (1985) evaluated the glutaraldehyde test for determination of fibrinogen and gammaglobulin in 435 adult cattle. They found that when externally manifest inflammatory processes are excluded, the presence of internal inflammatory diseases in animals..reacting positively within 3 minutes is accurately revealed in $97.8 \%$ and when within 6 minutes, it is accurate in $87.9 \%$ of the animals. The prognostic value of the test is similarly dependent upon the nature and localization of the process.

$S$ a d ho $1 \mathrm{~m} \mathrm{(1976)} \mathrm{and} 0$ ' $R$ g r $k e$ and $S$ a t e r f e ld (1981) view the glutaraldehyde coagulation test as a practical field test for identification of hypogammaglobulinemic newborn and young ruminants.

Our examinations of serum samples from calves were negative for longer than 60 minutes when they had been sampled before and several hours after colostrum intake. In older calves with non-coagulating sera we assume hypogammaglobulinemia resulting from delayed colostrum intake. This is confirmed by Te n a n t
et al. (1979) who found calf sera containing at least $0.6 \mathrm{~g} . \mathrm{dl}$ gammaglobulin coagulated within 60 minutes of glutaraldehyde contact.

Data from the literature and our results indicate that this test is a suitable tool for screening procedure for routine herd health monitoring. It can serve to direct the veterinarian toward further evaluation of those animals suffering from inflammatory processes and indentify young ruminants requiring treatment of hypogammaglobulinemia.

Vvužitelnost glutaraldehydového testu pri hovädzom dobytku

Za použitia glutaraldehydového testú sme sa zamerali na detekciu zápalových ochorení pri dospelom hovädzom dobytku a včasného ako aj dostatočného príjmu kolostra pri telatách. V rámci testovania celej krvi u dospelého hovädzieho dobytka sme z celkového poctu 368 kusov dojníc zistili 108 pozitivne reagujúcich zvierat do 6 minút. Po klinickom vyšetreni u týchto zvierat sme diagnostikovali : aktinomykózu, artritidu, bronchopneumóniu, endometritidu. uretritidu. hepatitidu. mastitidu, pododermatitídu, podkožný absces, perikarditídu, retikuloperitonitı́du a vaginitídu. Pri te- 
latách zo 67 testovaných kusov u 22 na základe nezrazenia sa séra bola zistená hypogamaglobulinémia, najčastejšie spósobená oneskoreným prijatím prvého kolostra. Pre jednoduchý princip metódy a rýchle ziskanie výsledkov glutaraldehydový test vhodne doplñuje diagnostické a preventívne zákroky praktického veterinárneho lekára.

Используемость глютаральдегидного теста у крупного рогатого скота

При использовании глютаральдегидного теста нами уделилось внимание выявлению воспалительных заболеваний взрослых особей крупного рогатого скота, а также своевренному и достаточному прнему молозива при наличии телят. В рамхах ициледования всей хрови взрослых голов из 368 дойниц хоров нами было выявлено 108 позитивно реагирующих животных до 6 минут. После клинического обследования упомянутых нами был поставлен диагноз: ахтиномикоза, артрита, бронхоревмонии,- эндометрита, уретрита, гепатита, мастита, падодерматита, подкожного абсцесса, перихардита, ретихулоперитонита и вагинита. При наличии теленка из 67 проверяемых голов у 22 на основе не свертывающейся сыворотки была установлена гипофаммаглобулинемия, вызванная чаще всего запоздалым приемом первого молозива. Благодаря простому принципу метода и быстрому получению результатов, глютаралдегидный тест является подиходящим дополнением диагностических и профилахтических. мер прахтического ветеринарного врача.

DOLL, K. - SCHILLINGER, D. - KLEE, W.: Der Glutaraldehyd-Test beim Rind - seine Brauchbarkeit für Diagnose und Prognose innerer Entzündungen. Zbl. Vet. Med. A., 32, 1985: 581-593. JAGOS, P. et al.: Diagnostika, terapie a prevence nemoci skotu. SZN, Praha 1985.

HOPWOOD, D.: A comparison of the crosslinking abilities of glutaraldehyde, formaldehyde and alpha-hydroxyadipaldehyde with bovine serum albumin and casein. Histochemie, 17, 1969: 151-161.

LIBERG, P.: Glutaraldehyde and formol-gel tests in bovine traumatic peritonitis. Acta vet. scand., 22, 1981: 78-84.

0 ROURKE, K. I. - SATTERFIELD, W. C.: GIutaraldehyde coagulation test for detection of hypogammaglobulinemia in neonatal nondomestic ruminants. J. Am. vet. med. Assoc., 179, 1981: 1144-1146 .

SANDHOLM, M.: A preliminary report of a rapid method for the demonstration of abnormal gammaglobulin levels in bovine whole blood. Res. vet. Sci., 17, 1974a: 32*35. 
SANDHOLM, M.: Die Feststellung der Hypergammaglobulinämie beim Rind unter Praxisbedingungen. Tierarzt1. Prax., 2, 1974: 237-240.

SANDHOLM, M.: Coagulation of serum by glutaraldehyde. Clin. Biochem., 9, 1976: 39-41.

SCHILLINGER, D.: Praxisnahe Laboruntersuchungen zur Diagnostik von Entzündungszuständen beim Rind. Prakt. Tierarzt, 63, 1982: 101-104.

TENNANT, B. - BALDWIN, B. H. - BRAUN, R. K. - NORCROSS, N. L. SANDHOLM, M.: Use of the glutaraldehyde coagulation test for detection of hypogammaglobulinemia in neonatal calves. J. Am. vet. med. Assoc., 174, 1979: 848-852.

VRZGULA, L. et al.: Vnútorné choroby prežúvavcov a ošlpaných. (Vybrané kapitoly.) Príroda, Bratislava 1980. 